\title{
The effect of blood glucose regulation on sarcopenia parameters in obese and diabetic patients
}

\author{
Zeynel Abidin Öztürk, ${ }^{1}$ İbrahim Halil Türkbeyler, ${ }^{1}$ Zeynep Demir, ${ }^{2}$ Muhammet Bilici, ${ }^{3}$ Yalçın Kepekçi ${ }^{3}$ \\ ${ }^{1}$ Department of Internal Medicine, Division of Geriatrics, Medical Faculty of Gaziantep University, Gaziantep, Turkey \\ ${ }^{2}$ Department of Radiology, New York University, Center for Biomedical Imaging, New York, USA \\ ${ }^{3}$ Department of Internal Medicine, Medical Faculty of Gaziantep University, Gaziantep, Turkey
}

Received: November 30, 2016 Accepted: April 21, 2017 Published online: November 14, 2017

\begin{abstract}
Objectives: This study aims to evaluate the effect of blood glucose regulation on sarcopenia parameters in sarcopenic, obese, and poorlyregulated diabetic patients.

Patients and methods: Between June 2013 and December 2013, a total of 147 patients (64 males, 83 females; mean age $70.3 \pm 6.3$ years; range, 60 to 90 years) who were diagnosed with sarcopenia according to the European Working Group on Sarcopenia in Older People (EWGSOP) criteria were included in the study. All patients were obese with a body mass index (BMI) of $>30 \mathrm{~kg} / \mathrm{m}^{2}$ and their glycated hemoglobin (HbAlc) levels were above $8 \%$. Sarcopenia parameters including the gait speed, muscle strength, muscle mass, and handgrip strength were assessed. After a six-month treatment period, the patients were divided into two groups according to their HbAlc levels as having $<8 \%$ or $>8 \%$. Sarcopenia parameters were evaluated before and after receiving treatment.

Results: The mean disease duration was $16 \pm 6.2$ years. Sixty patients were found to have a HbAlc level of $<8 \%$ and 45 patients with a HbAlc level of $\geq 8 \%$ at sixth months of follow-up. In better regulated group, sarcopenia parameters such as gait speed, muscle mass, and handgrip strength improved; however, only the change in the muscle mass was found to be statistically significant ( $\mathrm{p}=0.041)$. There was no significant change in the parameters of sarcopenia in the patient group with a HbAlc level $\geq 8 \%$. A negative correlation was found between the muscle mass and HbAlc levels in good- and poorly-regulated groups ( $\mathrm{p}=0.039 \mathrm{r}:-0.327$ and $\mathrm{p}=0.044 \mathrm{r}:-0.183$, respectively).

Conclusion: Our study demonstrates that lowering HbAlc levels may have positive effects on the muscle mass even in diabetic and sarcopenic obese elderly individuals.
\end{abstract}

Keywords: Diabetes mellitus; obesity; sarcopenia.

All over the world including developing countries, the life expectancy from birth has been increasing and, therefore, the number and rate of the elderly population has been increasing in recent years. ${ }^{[1]}$

Diabetes mellitus (DM) is a metabolic disorder which adversely affects the quality of life and life expectancy of elderly population. ${ }^{[2]}$ According to the data from the World Health Organization (WHO), $2.1 \%$ of the world's population is diabetic, and the incidence and prevalence have been on the rise with advanced age. ${ }^{[3]}$ In patients aged $\geq 65$ years old, DM accounts for $40 \%$ of all DM cases. ${ }^{[4]}$

Sarcopenia is characterized by progressive, generalized loss of muscle mass and strength, which is derived from Latin words sarx (muscle) and penia (loss). ${ }^{[5]}$ Although Rosenberg and Roubenoff ${ }^{[6]}$ first described sarcopenia as a reduction of skeletal muscle mass and size with aging, clinical description was made by Baumgartner et al. ${ }^{[7]}$ as muscle mass below two standard deviations of the mean of healthy young subjects muscle mass.

Obesity has reached to an epidemic proportion globally. It is no longer a problem solely affecting young individuals, but is also frequently seen among elderly. The prevalence of obesity in the United States was $22.9 \%$ between 60 and 69 years of age and $15.5 \%$ in age $>70$ years. ${ }^{[8]}$ The term of sarcopenic obesity was contributed to the literature with the increased

Corresponding author: İbrahim Halil Türkbeyler, MD. Gaziantep Üniversitesi Tıp Fakültesi İç Hastalıkları Anabilim Dalı, Geriatri Bilim Dalı, 27310 Şehitkamil, Gaziantep, Turkey. e-mail: turkbeyler@mynet.com 
incidence of obesity. ${ }^{[9]}$ Decreased lean body tissue and increased adipose tissue according to the body weight in elderly is defined as sarcopenic obesity of which the recognition has been more critical, recently. ${ }^{[10]}$

In recent years, sarcopenia has been accepted as one of the diabetic complications. ${ }^{[1]}$ However, its underlying mechanism in type 2 diabetes mellitus $\left(\mathrm{T}_{2} \mathrm{DM}\right)$ is still unclear. In this study, we aimed to evaluate the effect of blood glucose regulation on sarcopenia parameters in sarcopenic, obese, and poorly-regulated diabetic patients.

\section{PATIENTS AND METHODS}

Between June 2013 and December 2013, a total of 147 patients (64 males, 83 females; mean age $70.3 \pm 6.3$ years; range, 60 to 90 years) who were admitted to geriatric and/or internal medicine outpatient clinics and diagnosed with sarcopenia according to the European Working Group on Sarcopenia in Older People (EWGSOP) criteria were prospectively included in the study. All patients were obese with a body mass index (BMI) of $>30 \mathrm{~kg} / \mathrm{m}^{2}$ and their glycated hemoglobin (HbAlc) levels were above $8 \%$. Patients aged under 60 years, those with a debilitating disease or deformities, terminal stage disease, chronic liver and kidney diseases, malignancy, diabetic polineuropathy, history of trauma, and infection in the past one month, and poor cognitive function leading to failure to complete the study tests were excluded.

The demographic characteristics and comorbidities of the patients were recorded and the Mini-Nutritional Assessment (MNA), Activities of Daily Living Test, Geriatric Depression Scale, Mini-Mental State Examination (MMSE), and Get-up and Go-test were performed. In addition, complete blood cell count, urea, creatinine, liver function tests, calcium, and phosphorus levels were recorded. According to the EWGSOP, sarcopenia was defined as having low muscle mass plus low grip strength or low gait speed. ${ }^{[12]}$ Patients with sarcopenia according to the EWGSOP criteria and with a BMI of $\geq 30 \mathrm{~kg} / \mathrm{m}^{2}$ were considered sarcopenic obese.

In accordance with the diagnosis, the gait speed, muscle strength, and muscle mass were calculated. The gait speed was measured over six-meter-distance. The isometric hand grip strength is strongly related with lower extremity muscle power, knee extension torque, and calf cross-sectional muscle area. ${ }^{[13]}$ The muscle strength for hand grip strength was evaluated by an Tanita SA165 A-0950U-3 model electronic dynamometer device (Tanita Corp., Tokyo, Japan). The muscle mass was measured by bioelectrical impedance analysis (BIA) devices, which are useful tools to estimate the volume of fat and lean body mass, in our geriatric unit. In addition, anthropometric data were recorded such as weight, right, and left thigh and midupper arm circumference and waist circumference. Medical treatment was arranged and the patients were re-evaluated at sixth-month follow-up based on the same criteria. The patients were divided into two groups according to their $\mathrm{HbAlc}$ levels as having $<8 \%$ or $>8 \%$ and were analyzed based on changing parameters of sarcopenia.

The study protocol was approved by the local Ethics Committee. A written informed consent was obtained from each patient. The study was conducted in accordance with the principles of the Declaration of Helsinki.

\section{Statistical analysis}

Statistical analysis was performed using the SPSS for Windows version 15.0 software package (SPSS Inc., Chicago, IL, USA). Descriptive data were expressed in mean \pm standard deviation, median, and min-max. Paired sample t-test for binary comparisons of normally distributed numerical parameters, Mann-Whitney $\mathrm{U}$ test for abnormally distributed parameters, and the Pearson's chi-square test for categorical variables were used. Baseline and post-treatment normally distributed sarcopenia parameters were compared using the dependent Student's t-test. Since sarcopenia parameters and $\mathrm{HbAlc}$ showed normal distribution, the correlation coefficients $(r)$ and statistical significance were calculated using the Pearson's test: $\mathrm{r}$ near \pm 1 indicates a perfect correlation; $r$ between \pm 0.50 and \pm 1 indicates a strong relationship; $r$ between \pm 0.30 and \pm 0.49 indicates a moderate correlation; and $r$ below \pm 0.29 indicates a weak relationship. ${ }^{[14]} \mathrm{A} p$ value of $<0.05$ was considered statistically significant.

\section{RESULTS}

Of a total of 147 sarcopenic, diabetic, obese patients, the mean BMI was $33.2 \pm 3.1 \mathrm{~kg} / \mathrm{m}^{2}$, while the mean $\mathrm{HbAlc}$ level was $9.5 \pm 1.5 \%$. The mean disease duration was $16 \pm 6.2$ years. Of the patients, $61.2 \%$ were using insulin, $27.9 \%$ were taking oral antidiabetics, and $10.9 \%$ were taking insulin and oral antidiabetics concomitantly. Demographic characteristics, anthropometric measurements, comprehensive geriatric assessment test results, laboratory parameters, and related comorbidities are shown in Table 1. 
Table 1. Baseline demographic characteristics, anthropometric measurements, comprehensive geriatric assessment test results, laboratory results, and comorbidities of sarcopenic, diabetic obese patients

\begin{tabular}{|c|c|c|c|c|c|}
\hline & \multicolumn{5}{|c|}{ Diabetic patients with sarcopenic obesity $(\mathrm{n}=147)$} \\
\hline & $\bar{n}$ & $\%$ & Mean+SD & Median & Min-Max \\
\hline \multicolumn{6}{|l|}{ Demographic features } \\
\hline Age (year) & & & $70.3 \pm 6.3$ & & \\
\hline \multicolumn{6}{|l|}{ Sex } \\
\hline Male & 64 & 43.5 & & & \\
\hline Female & 83 & 56.5 & & & \\
\hline \multicolumn{6}{|l|}{ Anthropometric measurements } \\
\hline Calf circumference $(\mathrm{cm})$ & & & $37.1 \pm 4.4$ & & \\
\hline Body mass index $\left(\mathrm{kg} / \mathrm{m}^{2}\right)$ & & & $33.2 \pm 3.1$ & & \\
\hline Waist circumference $(\mathrm{cm})$ & & & $104.3 \pm 11.0$ & & \\
\hline Hip circumference $(\mathrm{cm})$ & & & $112.8 \pm 14.6$ & & \\
\hline Mid-upper arm circumference $(\mathrm{cm})$ & & & $34.2 \pm 5.2$ & & \\
\hline \multicolumn{6}{|l|}{ Comprehensive geriatric assessment tests } \\
\hline Activities of Daily Living test & & & & 2 & $0-20$ \\
\hline Mini-Nutritional Assessment test-short form & & & $12.6 \pm 1.4$ & & \\
\hline Mini-cog test & & & $26.6 \pm 3.4$ & & \\
\hline Geriatric Depression scale & & & $5.2 \pm 2.3$ & & \\
\hline Timed Up and Go test & & & $7.4 \pm 2.2$ & & \\
\hline \multicolumn{6}{|l|}{ Laboratory parameters } \\
\hline Hemoglobin $(\mathrm{g} / \mathrm{dL})$ & & & $13.4 \pm 1.5$ & & \\
\hline White blood cell $\left(/ \mathrm{mm}^{3}\right)$ & & & $7,930 \pm 2,454$ & & \\
\hline Platelets $\left(/ \mathrm{mm}^{3}\right)$ & & & $274,040 \pm 61,820$ & & \\
\hline Erythrocyte sedimentation rate $(\mathrm{mm} / \mathrm{h})$ & & & & 31 & $4-110$ \\
\hline C-reactive protein $(\mathrm{mg} / \mathrm{dL})$ & & & & 11 & $1-112$ \\
\hline Blood urea nitrogen $(\mathrm{mg} / \mathrm{dL})$ & & & $28.4 \pm 12.5$ & & \\
\hline Creatinine $(\mathrm{mg} / \mathrm{dL})$ & & & $0.9 \pm 0.3$ & & \\
\hline Alanine aminotransferase (U/L) & & & $24.1 \pm 16.3$ & & \\
\hline Aspartate aminotransferase (U/L) & & & $32.4 \pm 20.0$ & & \\
\hline Vitamin B12 (pg/mL) & & & $284.1 \pm 165.1$ & & \\
\hline Total cholesterol (mg/dL) & & & $198.2 \pm 26.6$ & & \\
\hline Albumin $(\mathrm{g} / \mathrm{dL})$ & & & $3.5 \pm 0.6$ & & \\
\hline HbAlc $(\%)$ & & & $9.5 \pm 1.5$ & & \\
\hline
\end{tabular}

SD: Standard deviation; Min: Minimum; Max: Maximum; HbAlc: Hemoglobin Alc.

Table 2. Post-treatment demographic characteristics, anthropometric measurements, comprehensive geriatric assessment test results, laboratory results, and comorbidities of sarcopenic, diabetic obese patients at six months

\begin{tabular}{|c|c|c|c|c|c|c|c|c|c|c|c|}
\hline & \multicolumn{5}{|c|}{ HbA1c $<8$ sarcopenic obese patients $(n=60)$} & \multicolumn{5}{|c|}{ HbAlc $>8$ sarcopenic obese patients $(n=45)$} & \multirow[b]{2}{*}{$p$} \\
\hline & $\mathrm{n}$ & $\%$ & Mean+SD & Median & Min-Max & $\mathrm{n}$ & $\%$ & Mean+SD & Median & Min-Max & \\
\hline \multicolumn{12}{|l|}{ Demographic features } \\
\hline Age (year) & & & $69.6 \pm 5.4$ & & & & & $68.3 \pm 5.7$ & & & $0.021^{*}$ \\
\hline Sex & & & & & & & & & & & 0.062 \\
\hline Male & 24 & 40 & & & & 20 & 44.4 & & & & \\
\hline Female & 36 & 60 & & & & 25 & 55.6 & & & & \\
\hline \multicolumn{12}{|l|}{ Anthropometric measurements } \\
\hline Calf circumference $(\mathrm{cm})$ & & & $36.7 \pm 5.8$ & & & & & $38.5 \pm 6.1$ & & & $<0.001^{*}$ \\
\hline Body mass index $\left(\mathrm{kg} / \mathrm{m}^{2}\right)$ & & & $32.7 \pm 3.3$ & & & & & $33.8 \pm 3.9$ & & & $0.026^{*}$ \\
\hline Waist circumference $(\mathrm{cm})$ & & & $102.3 \pm 15.8$ & & & & & $104.2 \pm 16.1$ & & & $0.009^{*}$ \\
\hline Hip circumference $(\mathrm{cm})$ & & & $109.4 \pm 14.3$ & & & & & $111.7 \pm 12.4$ & & & $0.036^{*}$ \\
\hline Mid-upper arm circumference $(\mathrm{cm})$ & & & $33.2 \pm 3.1$ & & & & & $34.1 \pm 4.6$ & & & 0.074 \\
\hline \multicolumn{12}{|l|}{ Comprehensive Geriatric Assessment tests } \\
\hline Activities of Daily Living test & & & & 2 & $0-20$ & & & & 3 & $0-20$ & 0.055 \\
\hline $\begin{array}{l}\text { Mini-Nutritional Assessment } \\
\text { test-short Form }\end{array}$ & & & & & & & & & & & \\
\hline Mini-cog test & & & $26.3 \pm 4.9$ & & & & & $\begin{array}{l}12.8 \pm 2.2 \\
26.0 \pm 4.4\end{array}$ & & & $\begin{array}{l}0.284 \\
0.342\end{array}$ \\
\hline Geriatric Depression scale & & & $4.8 \pm 2.4$ & & & & & $5.2 \pm 2.5$ & & & $0.044^{*}$ \\
\hline Timed Up and Go test & & & $7.0 \pm 1.4$ & & & & & $7.3 \pm 1.9$ & & & $0.035^{*}$ \\
\hline \multicolumn{12}{|l|}{ Laboratory parameters } \\
\hline Hemoglobin (g/dL) & & & $13.2 \pm 1.9$ & & & & & $13.6 \pm 2.11$ & & & 0.114 \\
\hline White blood cell $\left(/ \mathrm{mm}^{3}\right)$ & & & $7,910 \pm 2,325$ & & & & & $7,360 \pm 2,145$ & & & 0.662 \\
\hline Platelets $\left(/ \mathrm{mm}^{3}\right)$ & & & $284,120 \pm 64,505$ & & & & & $257,445 \pm 70,280$ & & & 0.084 \\
\hline Erythrocyte sedimentation rate $(\mathrm{mm} / \mathrm{h})$ & & & & 34 & $10-110$ & & & & 31 & $8-110$ & 0.278 \\
\hline C-reactive protein $(\mathrm{mg} / \mathrm{dL})$ & & & & 7 & $0-32$ & & & & 6 & $0-66$ & 0.284 \\
\hline Blood urea nitrogen $(\mathrm{mg} / \mathrm{dL})$ & & & $36.4 \pm 14.3$ & & & & & $29.3 \pm 11.5$ & & & 0.728 \\
\hline Creatinine (mg/dL) & & & $0.9 \pm 0.3$ & & & & & $1.0 \pm 0.2$ & & & 0.108 \\
\hline Alanine aminotransferase $(\mathrm{U} / \mathrm{L})$ & & & $24.6 \pm 12.4$ & & & & & $21.2 \pm 5.5$ & & & 0.365 \\
\hline Aspartate aminotransferase (U/L) & & & $28.2 \pm 16.1$ & & & & & $32.4 \pm 14.2$ & & & 0.478 \\
\hline Vitamin B12 (pg/mL) & & & $346.0 \pm 108.1$ & & & & & $363.2 \pm 147.3$ & & & 0.912 \\
\hline Albumin $(\mathrm{g} / \mathrm{dL})$ & & & $3.9 \pm 0.6$ & & & & & $4.0 \pm 0.4$ & & & 0.275 \\
\hline HbAlc (\%) & & & $7.6 \pm 2.1$ & & & & & $8.9 \pm 2.8$ & & & $0.029^{*}$ \\
\hline
\end{tabular}

SD: Standard deviation; Min: Minimum; Max: Maximum; HbAlc: Hemoglobin Alc. 
Table 3. Difference between baseline and post-treatment evaluation on sarcopenia parameters in patient with level of $\mathrm{HbAlc}<8 \%$

\begin{tabular}{lcccc}
\hline Sarcopenia diagnostic criteria & First evaluation & & \multicolumn{2}{l}{ Second evaluation } \\
\cline { 2 - 2 } & Mean & & Mean & $p$ \\
\hline Gait speed $(\mathrm{m} / \mathrm{s})$ & 0.76 & & 0.78 & 0.143 \\
Muscle mass $\left(\mathrm{kg} / \mathrm{m}^{2}\right)$ & 7.42 & & 7.64 & $0.041^{*}$ \\
Hand grip strength $(\mathrm{kg})$ & 24.51 & & 25.08 & 0.184 \\
\hline
\end{tabular}

Table 4. Difference between baseline and post-treatment evaluation on sarcopenia parameters in patient with level of $\mathrm{HbAlc} \geq 8 \%$

\begin{tabular}{lcccc}
\hline Sarcopenia diagnostic criteria & First evaluation & & \multicolumn{2}{c}{ Second evaluation } \\
\cline { 2 - 2 } & Mean & & Mean & $p$ \\
\hline Gait speed $(\mathrm{m} / \mathrm{s})$ & 0.72 & & 0.71 & 0.257 \\
Muscle mass $\left(\mathrm{kg} / \mathrm{m}^{2}\right)$ & 7.37 & & 7.36 & 0.197 \\
Hand grip strength $(\mathrm{kg})$ & 25.74 & & 24.85 & 0.351 \\
\hline
\end{tabular}

The mean gait speed was measured as $0.73 \mathrm{~m} / \mathrm{s}$, the mean muscle mass as $7.32 \mathrm{~kg} / \mathrm{m}^{2}$, and the mean hand strength as $24.04 \mathrm{~kg}$. Since 42 of the patients initially included in the study were unable to complete sixmonth follow-up, they were eventually excluded from the analysis. The remaining patients were divided into two groups based on their HbAlc levels as having $<8 \%$ and $\geq 8 \%$ after six months of treatment. The demographic characteristics, anthropometric measurements, comprehensive geriatric assessment test results, and laboratory parameters of these two groups are shown in Table 2 . For the HbAlc $<8 \%$ group, values for calf circumference, BMI, waist and hip circumference were measured statistically significantly lower, compared to the other group $(\mathrm{p}<0.001, \mathrm{p}=0.026$, $\mathrm{p}=0.009$, and $\mathrm{p}=0.036$, respectively). However, daily activities, MNA-Short Form, and MMSE did not indicate a significant difference between the groups $(\mathrm{p}=0.055, \mathrm{p}=0.284$, and $\mathrm{p}=0.342$, respectively). On the other hand, lower results were found using the Geriatric Depression Scale and Get-up and Go-test for the HbAlc $>8 \%$ group $(4.8 \pm 2.4$ and $5.2 \pm 2.5, \mathrm{p}=0.044$; $7.0 \pm 1.4$ and $7.3 \pm 1.9, \mathrm{p}=0.035$, respectively). The mean HbAlc level was found to be $7.62 \% \pm 2.14 \%$ in the group with good blood glucose regulation and to be $8.9 \pm 2.8$ in the group with poor blood glucose regulation

Table 5. The correlation between sarcopenia parameters with $\mathrm{HbA1c}$ in patients with level of HbA1c $<8 \%$

\begin{tabular}{lcc}
\hline Parameters & $p$ & \multicolumn{1}{c}{$\mathrm{r}$} \\
\hline HbAlc-Gait speed & 0.058 & -0.156 \\
HbAlc-Muscle mass & 0.039 & $-0.327^{*}$ \\
HbAlc-Hand grip strength & 0.062 & -0.161 \\
\hline
\end{tabular}

$(\mathrm{p}=0.029)$. The changes in the sarcopenia parameters of both groups during the initial evaluations and at sixmonth follow-up are shown in Tables 3 and 4 . Although an increase was observed in all three parameters (gait speed, muscle mass, and hand grip strength) in the $\mathrm{HbAlc}<8 \%$ group, only the increase in the muscle mass reached statistical significance in this group ( $\mathrm{p}=0.041)$. In the poor blood glucose regulation group, all three parameters indicated a decline; however, none of these changes was statistically significant $(p=0.257$, $\mathrm{p}=0.197$, and $\mathrm{p}=0.351$, respectively). The correlation between the level of HbAlc and sarcopenia parameters are shown in Tables 5 and 6. For both good and poor blood regulation groups, a significant negative correlation was found between the muscle mass and HbAlc level ( $p=0.039, r:-0.327$ and $p=0.044, r:-0.183$, respectively).

\section{DISCUSSION}

In this prospective study, diabetic and sarcopenic obese elderly patients were followed for six months, and the patients with improved blood glucose regulation demonstrated improved values in sarcopenia parameters including the gait speed, muscle mass, and hand grip strength test, while no improvement was

Table 6. The correlation between sarcopenia parameters with HbAlc in patients with level of HbAlc $\geq 8 \%$

\begin{tabular}{lcc}
\hline Parameters & $p$ & $\mathrm{r}$ \\
\hline HbAlc-Gait speed & 0.134 & -0.233 \\
HbAlc-Muscle mass & 0.044 & $-0.183^{*}$ \\
HbAlc-Hand grip strength & 0.211 & -0.247 \\
\hline
\end{tabular}


observed in the poor blood glucose regulation group. Furthermore, the changes in the muscle mass within six months were found to be statistically significant in the group with $\mathrm{HbAlc}<8 \%$. Based on the examination of the correlation between the Hb1Ac levels and sarcopenia parameters, we found a negative correlation between the Hb1Ac levels and the muscle mass in both groups. This negative correlation was moderate in good blood glucose regulation group and weak in the other group.

Although type 1 diabetes evidently affects protein metabolism by specifically increasing catabolism in the skeletal muscles due to lack of insulin, ${ }^{[15]} \mathrm{T}_{2} \mathrm{DM}$ has a less evident effect on the protein metabolism, and the results of previous studies are controversial. ${ }^{[16-20]}$ The muscle loss in $\mathrm{T}_{2} \mathrm{DM}$ may be caused by insulin resistance, which leads to a decline in the protein synthesis and increase in the protein degradation. ${ }^{[21]}$ Insulin as an anabolic hormone may induce muscle protein synthesis in young individuals; however, similar effects cannot be seen in older population. Supraphysiological insulin concentrations may bridge the gap between age-related insulin resistances of the muscle protein synthesis. ${ }^{[22]}$ In addition, insulin resistance may contribute to the muscle loss in diabetes, by inactivating the mammalian target of rapamycin (mTOR) pathway and stimulating autophagy. ${ }^{[23,24]}$ A recent experimental study by Nilsson et al. ${ }^{[25]}$ showed that level of the domain-containing mTOR-interacting protein (DEPTOR), an endogenous mTOR inhibitor, was critical in the regulation of protein turnover in sarcopenic obese rats. Not only skeletal muscle size and mass reduced, bioenergy systems of the body including mitochondrial function may be also altered in these patients. ${ }^{[26-29]}$ In the muscles of patients with $\mathrm{T}_{2} \mathrm{DM}$, peroxisome proliferator-activated receptor gamma coactivator, a transcriptional coactivator, can reduce gene expression and may contribute to prohibit muscle atrophy. ${ }^{[30,31]}$ In addition, diabetes is characterized by decreased mitochondrial electron transport chain activity which leads to inefficient energy. ${ }^{[32,33]}$ Nonetheless, insulin supplementation in non-diabetic population causes an increase of adenosine triphosphate (ATP) production in the skeletal muscles, while the same effect is not seen in diabetic population which may be related to impaired insulin response. ${ }^{[34]}$ Patients with diabetes also show a lower in vivo mitochondrial function in muscles as measured with phophorus-31 magnetic resonance spectroscopy, than age-matched and BMI-matched controls. ${ }^{[35]}$
The first epidemiological study showing the effect of $\mathrm{T}_{2} \mathrm{DM}$ on the muscle strength and mass was conducted by Park et al. ${ }^{[36]}$ The arm and leg muscle strength and mass of a total of 1,840 elderly individuals were examined during three years, and the final results showed a $13.5 \%$ decrease in the knee extensor muscle strength in patients with $\mathrm{T}_{2} \mathrm{DM}$ and a $9 \%$ decrease in individuals without diabetes. The authors also demonstrated a more rapid decline in the muscle quality in older diabetic patients, and diabetes was associated with functional impairment of the lower extremity muscles without losing any muscle mass. According to the results, the authors found no correlation between the changes in the muscle strengths of the upper and lower extremities. On the other hand, some other studies indicated better maintenance of the muscle strength in the upper extremities with aging. ${ }^{[37,38]}$ Our study did not demonstrate any significant changes in the muscle strengths of the upper extremities in either groups during a six-month follow-up period. In another study, Park et al. ${ }^{[39]}$ reported a rapid loss of skeletal muscle mass in elderly patients with $\mathrm{T}_{2} \mathrm{DM}$. Intriguingly, decreased muscle mass was higher in undiagnosed diabetic individuals, indicating that $\mathrm{T}_{2} \mathrm{DM}$ begins to affect the muscle mass from early stages of the disease. There is also a negative linear relationship between the muscle quality and duration of diabetes and poor glycemic control. ${ }^{[40]}$ Insufficient energy use and muscle protein degradation occur depending on the severity of catabolism caused by uncontrolled hyperglycemia. This progression leads to sarcopenia and fatty infiltration of muscle tissue, resulting in limited functional capacity of the muscle. In diabetic individuals with poor glycemic control, increased tumor necrosis factor-alpha and inflammatory cytokines such as interleukin-6 in the muscle tissue induce apoptosis, leading to the destruction of the muscular structure. ${ }^{[41,42]}$

The Korea Sarcopenic Obesity Study showed that sarcopenia was more common in elderly individuals with $\mathrm{T}_{2} \mathrm{DM}$ (6.9 to $\left.15.7 \%\right){ }^{[43]}$ Sarcopenic obese adults also had higher cardiovascular disease risk than non-sarcopenic obese adults. ${ }^{[4]}$ The Third National Health and Nutrition Survey Study found a negative correlation between the skeletal muscle index and insulin resistance, $\mathrm{HbAlc}$, and diabetes-prediabetes prevalence. ${ }^{[45]}$ Tanaka et al. ${ }^{[46]}$ concluded that the levels of endogenous insulin were positively associated with indices of the muscle mass independently of serum IGF-I in patients with $\mathrm{T}_{2} \mathrm{DM}$ and they suggested that reduction in endogenous insulin was an independent 
risk factor for diabetes-related sarcopenia, and maintaining endogenous insulin was critical to prevent it.

In another study, there was evident overexpression of messenger ribonucleic acid (mRNA) for myostatin, a peptide in the muscle of patients with $\mathrm{T}_{2} \mathrm{DM}$ which negatively regulates the skeletal muscle mass. ${ }^{[47]}$ Physiological responses to exercise and nutrition were impaired and anti-proteolytic effects of insulin decreased. As a potent growth factor, insulin increases collagen synthesis, and stimulates arterial smooth muscle proliferation. ${ }^{[48,49]}$ Insulin resistance leads to impaired vasodilation, increased oxidative stress, and chronic inflammation by released high concentration of non-esterified fatty acids, vasoconstrictors, cellular adhesion molecules, and the other mediators. ${ }^{[50]}$ While sarcopenia negatively affects insulin sensitivity and increases insulin resistance, this resistance aggravates to sarcopenia by increasing the loss of skeletal muscle.

Although overweight and obesity are more common in older diabetic individuals, higher BMI values are proportional to increased fat infiltration in the muscle tissue. As increased intramuscular fat infiltration is associated with oxidative activity and a reduction of maximum aerobic capacity, epidemiological studies have indicated muscle fat infiltration as a predictor of developing mobility limitations in older individuals. ${ }^{[51]}$ Mogi et al. ${ }^{[52]}$ demonstrated that diabetic mice had increased intramuscular fat deposition due to unusual cell differentiation.

Walking performance in older individuals provides information about the general health status and functional capacity and is helpful to predict disability, life expectancy, and other important health parameters. ${ }^{[53,54]}$ A study by Volpato et al. ${ }^{[55]}$ although the calf circumference of diabetic elderly patients was wider than the non-diabetic individuals, the muscle strength, muscle quality, and gait speed values were lower. Our results indicating lower gait speed in the patients with poor blood glucose regulation also support this finding. Moreover, the muscle strength, gait speed, and muscle quality in diabetic and nondiabetic elderly patients were evaluated independently from motor neuropathy and peripheral arterial disease, suggesting a direct effect of diabetes on the muscle structure and performance.

Nonetheless, there are some limitations to this study. First, we were unable to evaluate the effect of different medications on sarcopenic obesity due to small sample size in each treatment group in which we allowed cross-over from one to another during follow-up.
Second, we were unable to examine insulin resistance. Although we are aware of that there is a correspondent interaction between sarcopenia and insulin resistance, this relationship has been, so far, evaluated only in cross-sectional studies, but not in prospective studies. Our third limitation is that neurophysiological studies were unable to be conducted to evaluate the initial and post-treatment nerve conduction velocity.

In conclusion, our study is considerably significant, as it is the first study to evaluate the changes in the parameters of sarcopenia and the decline in the HbAlc levels during a six-month follow-up period in older patients with obesity, sarcopenia, and diabetes mellitus. Even in a six-month period, we observed significant increases in the muscle mass by regulating blood glucose. In addition, we found a negative correlation between the HbAlc levels and muscle mass. Based on our study results, we suggest that patients should be followed for longer periods of time to obtain more detailed information about the muscle quality and functionality in elderly.

\section{Declaration of conflicting interests}

The authors declared no conflicts of interest with respect to the authorship and/or publication of this article.

\section{Funding}

The authors received no financial support for the research and/or authorship of this article.

\section{REFERENCES}

1. Wang C, Bai L. Sarcopenia in the elderly: basic and clinical issues. Geriatr Gerontol Int 2012;12:388-96.

2. Andrade F. Estimating diabetes and diabetes-free life expectancy in Mexico and seven major cities in Latin America and the Caribbean. Rev Panam Salud Publica 2009;26:9-16.

3. Cho EH, Shin D, Cho KH, Hur J. Prevalences and Management of Diabetes and Pre-diabetes among Korean Teenagers and Young Adults: Results from the Korea National Health and Nutrition Examination Survey 20052014. J Korean Med Sci 2017;32:1984-90.

4. Ho PJ, Turtle JR. Establishing the Diagnosis. In: Sinclair AJ, Finucane P, editors. Diabetes in Old Age. 2nd ed. Chichester: John Wiley \& Sons; 2000. p. 00-00.

5. Burton LA, Sumukadas D. Optimal management of sarcopenia. Clin Interv Aging 2010;5:217-28.

6. Rosenberg IH, Roubenoff R. Stalking sarcopenia. Ann Intern Med 1995;123:727-8.

7. Baumgartner RN, Koehler KM, Gallagher D, Romero L, Heymsfield SB, Ross RR, et al. Epidemiology of sarcopenia among the elderly in New Mexico. Am J Epidemiol 1998;147:755-63.

8. Elia M. Obesity in the elderly. Obes Res 2001;9 Suppl $4: 244$ S-248S. 
9. An KO, Kim J. Association of Sarcopenia and Obesity With Multimorbidity in Korean Adults: A Nationwide CrossSectional Study. J Am Med Dir Assoc 2016;17:960.e1-7.

10. Ruiz-Arregui L, Castillo-Martínez L, Orea-Tejeda A, MejíaArango S, Miguel-Jaimes A. Prevalence of self-reported overweight-obesity and its association with socioeconomic and health factors among older Mexican adults. Salud Publica Mex 2007;49:482-7.

11. Andersen H, Nielsen S, Mogensen CE, Jakobsen J. Muscle strength in type 2 diabetes. Diabetes 2004;53:1543-8.

12. Cruz-Jentoft AJ, Baeyens JP, Bauer JM, Boirie Y, Cederholm T, Landi F, et al. Sarcopenia: European consensus on definition and diagnosis: Report of the European Working Group on Sarcopenia in Older People. Age Ageing 2010;39:412-23.

13. Fragala MS, Alley DE, Shardell MD, Harris TB, McLean RR, Kiel DP, et al. Comparison of handgrip and leg extension strength in predicting slow gait speed in older adults. J Am Geriatr Soc 2016;64:144-50.

14. Available from: https://explorable.com/statisticalcorrelation

15. Charlton M, Nair KS. Protein metabolism in insulindependent diabetes mellitus. J Nutr 1998;128:323-7.

16. Karakelides H, Asmann YW, Bigelow ML, Short KR, Dhatariya K, Coenen-Schimke J, et al. Effect of insulin deprivation on muscle mitochondrial ATP production and gene transcript levels in type 1 diabetic subjects. Diabetes 2007;56:2683-9.

17. Halvatsiotis P, Short KR, Bigelow M, Nair KS. Synthesis rate of muscle proteins, muscle functions, and amino acid kinetics in type 2 diabetes. Diabetes 2002;51:2395-404.

18. Gougeon R, Morais JA, Chevalier S, Pereira S, Lamarche M, Marliss EB. Determinants of whole-body protein metabolism in subjects with and without type 2 diabetes. Diabetes Care 2008;31:128-33.

19. Pereira S, Marliss EB, Morais JA, Chevalier S, Gougeon R. Insulin resistance of protein metabolism in type 2 diabetes. Diabetes 2008;57:56-63.

20. Denne SC, Brechtel G, Johnson A, Liechty EA, Baron AD. Skeletal muscle proteolysis is reduced in noninsulindependent diabetes mellitus and is unaltered by euglycemic hyperinsulinemia or intensive insulin therapy. J Clin Endocrinol Metab 1995;80:2371-7.

21. Ohsawa M, Murakami T, Kume K. Possible involvement of insulin resistance in the progression of cancer cachexia in mice. Yakugaku Zasshi 2016;136:687-92. [Abstract]

22. Fujita S, Glynn EL, Timmerman KL, Rasmussen BB, Volpi E. Supraphysiological hyperinsulinaemia is necessary to stimulate skeletal muscle protein anabolism in older adults: evidence of a true age-related insulin resistance of muscle protein metabolism. Diabetologia 2009;52:1889-98.

23. Kaushik S, Singh R, Cuervo AM. Autophagic pathways and metabolic stress. Diabetes Obes Metab 2010;12:4-14.

24. Wang $\mathrm{X}, \mathrm{Hu} \mathrm{Z}, \mathrm{Hu} \mathrm{J}, \mathrm{Du} \mathrm{J}$, Mitch WE. Insulin resistance accelerates muscle protein degradation: Activation of the ubiquitin-proteasome pathway by defects in muscle cell signaling. Endocrinology 2006;147:4160-8.
25. Nilsson MI, Dobson JP, Greene NP, Wiggs MP, Shimkus $\mathrm{KL}$, Wudeck EV, et al. Abnormal protein turnover and anabolic resistance to exercise in sarcopenic obesity. FASEB J 2013;27:3905-16.

26. Sandri M, Lin J, Handschin C, Yang W, Arany ZP, Lecker $\mathrm{SH}$, et al. PGC-1alpha protects skeletal muscle from atrophy by suppressing FoxO3 action and atrophyspecific gene transcription. Proc Natl Acad Sci U S A 2006;103:16260-5.

27. Kelley DE, He J, Menshikova EV, Ritov VB. Dysfunction of mitochondria in human skeletal muscle in type 2 diabetes. Diabetes 2002;51:2944-50.

28. Jerusalem F, Engel AG, Peterson HA. Human muscle fiber fine structure: morphometric data on controls. Neurology 1975;25:127-34.

29. Boushel R, Gnaiger E, Schjerling P, Skovbro M, Kraunsøe R, Dela F. Patients with type 2 diabetes have normal mitochondrial function in skeletal muscle. Diabetologia 2007;50:790-6.

30. Patti ME, Butte AJ, Crunkhorn S, Cusi K, Berria R, Kashyap $S$, et al. Coordinated reduction of genes of oxidative metabolism in humans with insulin resistance and diabetes: Potential role of PGC1 and NRF1. Proc Natl Acad Sci U S A 2003;100:8466-71.

31. Lira VA, Benton CR, Yan Z, Bonen A. PGC-1alpha regulation by exercise training and its influences on muscle function and insulin sensitivity. Am J Physiol Endocrinol Metab 2010;299:145-61.

32. Mogensen M, Sahlin K, Fernström M, Glintborg D, Vind $\mathrm{BF}$, Beck-Nielsen $\mathrm{H}$, et al. Mitochondrial respiration is decreased in skeletal muscle of patients with type 2 diabetes. Diabetes 2007;56:1592-9.

33. Phielix E, Mensink M. Type 2 diabetes mellitus and skeletal muscle metabolic function. Physiol Behav 2008;94:252-8.

34. Stump CS, Short KR, Bigelow ML, Schimke JM, Nair KS. Effect of insulin on human skeletal muscle mitochondrial ATP production, protein synthesis, and mRNA transcripts. Proc Natl Acad Sci U S A 2003;100:7996-8001.

35. Schrauwen-Hinderling VB, Kooi ME, Hesselink MK, Jeneson JA, Backes WH, van Echteld CJ, et al. Impaired in vivo mitochondrial function but similar intramyocellular lipid content in patients with type 2 diabetes mellitus and BMImatched control subjects. Diabetologia 2007;50:113-20.

36. Park SW, Goodpaster BH, Strotmeyer ES, Kuller LH, Broudeau $\mathrm{R}$, Kammerer C, et al. Accelerated loss of skeletal muscle strength in older adults with type 2 diabetes: the health, aging, and body composition study. Diabetes Care 2007;30:1507-12.

37. Newman AB, Haggerty CL, Goodpaster B, Harris T, Kritchevsky S, Nevitt M, et al. Strength and muscle quality in a well-functioning cohort of older adults: the Health, Aging and Body Composition Study. J Am Geriatr Soc 2003;51:323-30.

38. Frontera WR, Hughes VA, Fielding RA, Fiatarone MA, Evans WJ, Roubenoff R. Aging of skeletal muscle: a 12-yr longitudinal study. J Appl Physiol (1985) 2000;88:1321-6.

39. Park SW, Goodpaster BH, Lee JS, Kuller LH, Boudreau $\mathrm{R}$, de Rekeneire N, et al. Excessive loss of skeletal muscle mass in older adults with type 2 diabetes. Diabetes Care 2009;32:1993-7. 
40. Park SW, Goodpaster BH, Strotmeyer ES, de Rekeneire N, Harris TB, Schwartz AV, et al. Decreased muscle strength and quality in older adults with type 2 diabetes: the health, aging, and body composition study. Diabetes 2006;55:1813-8.

41. Helmersson J, Vessby B, Larsson A, Basu S. Association of type 2 diabetes with cyclooxygenase-mediated inflammation and oxidative stress in an elderly population. Circulation 2004;109:1729-34.

42. Visser M, Pahor M, Taaffe DR, Goodpaster BH, Simonsick EM, Newman AB, et al. Relationship of interleukin- 6 and tumor necrosis factor-alpha with muscle mass and muscle strength in elderly men and women: the Health ABC Study. J Gerontol A Biol Sci Med Sci 2002;57:326-32.

43. Kim TN, Park MS, Yang SJ, Yoo HJ, Kang HJ, Song W, et al. Prevalence and determinant factors of sarcopenia in patients with type 2 diabetes: the Korean Sarcopenic Obesity Study (KSOS). Diabetes Care 2010;33:1497-9.

44. Kim JH, Cho JJ, Park YS. Relationship between sarcopenic obesity and cardiovascular disease risk as estimated by the Framingham risk score. J Korean Med Sci 2015;30:264-71.

45. Srikanthan P, Karlamangla AS. Relative muscle mass is inversely associated with insulin resistance and prediabetes. Findings from the third National Health and Nutrition Examination Survey. J Clin Endocrinol Metab 2011;96:2898-903.

46. Tanaka K, Kanazawa I, Sugimoto T. Reduction in Endogenous Insulin Secretion is a Risk Factor of Sarcopenia in Men with Type 2 Diabetes Mellitus. Calcif Tissue Int 2015;97:385-90.

47. Brandt C, Nielsen AR, Fischer CP, Hansen J, Pedersen BK, Plomgaard P. Plasma and muscle myostatin in relation to type 2 diabetes. PLoS One 2012;7:e37236.

48. Murphy J, Chevalier S, Gougeon R, Goulet ÉD, Morais JA. Effect of obesity and type 2 diabetes on protein anabolic response to insulin in elderly women. Exp Gerontol 2015;69:20-6.
49. Kwon SS, Lee SG, Lee YH, Lim JB, Kim JH. Homeostasis model assessment of insulin resistance in a general adult population in Korea: additive association of sarcopenia and obesity with insulin resistance. Clin Endocrinol (Oxf) 2017;86:44-51.

50. Matulewicz N, Karczewska-Kupczewska M. Insulin resistance and chronic inflammation. Postepy Hig Med Dosw (Online) 2016;70:1245-58.

51. Visser M, Goodpaster BH, Kritchevsky SB, Newman AB, Nevitt M, Rubin SM, et al. Muscle mass, muscle strength, and muscle fat infiltration as predictors of incident mobility limitations in well-functioning older persons. J Gerontol A Biol Sci Med Sci 2005;60:324-33.

52. Mogi M, Kohara K, Nakaoka H, Kan-No H, Tsukuda K, Wang XL, et al. Diabetic mice exhibited a peculiar alteration in body composition with exaggerated ectopic fat deposition after muscle injury due to anomalous cell differentiation. J Cachexia Sarcopenia Muscle 2016;7:213-24.

53. Guralnik JM, Ferrucci L, Pieper CF, Leveille SG, Markides $\mathrm{KS}$, Ostir GV, et al. Lower extremity function and subsequent disability: consistency across studies, predictive models, and value of gait speed alone compared with the short physical performance battery. J Gerontol A Biol Sci Med Sci 2000;55:221-31.

54. Newman AB, Simonsick EM, Naydeck BL, Boudreau RM, Kritchevsky SB, Nevitt MC, et al. Association of long-distance corridor walk performance with mortality, cardiovascular disease, mobility limitation, and disability. JAMA 2006;295:2018-26.

55. Volpato S, Bianchi L, Lauretani F, Lauretani F, Bandinelli S, Guralnik JM, et al. Role of muscle mass and muscle quality in the association between diabetes and gait speed. Diabetes Care 2012;35:1672-9. 